\title{
The Effect of Speech Therapy with Hijaiyyah Letters on the Capability of Verbal Communication at Stroke Patients
}

\author{
$1^{\text {st }}$ Sukarmin \\ Keperawatan, Muhammadiyah \\ University of Kudus \\ Indonesia \\ sukarmin@umkudus.ac.id
}

\author{
$2^{\text {nd }}$ Muhammad Abdur Rozaq \\ Department Midwifery \\ Keperawatan, Muhammadiyah \\ University of Kudus \\ Indonesia
}

\author{
$3^{\text {rd }}$ Toni Ardi Rafsanjani \\ Keperawatan, Muhammadiyah \\ University of Kudus \\ Indonesia
}

\begin{abstract}
The purpose of research to know the influence of speech therapy with hijaiyyah letters toward verbal communication ability at stroke patients. This research used experiment research method with one group pre test-post test design. Hypothesis that there is not difference was evidenced verbal communication skills after speech therapy. Samples in this study were stroke non haemorragic patients with aphasia symptoms in dr. Loekmono Hadi Kudus General Hospital from July to September 2019 as many as 20 patients. This study uses accidental sampling. Result there are significant difference on verbal communication ability respondent before and after being treatment by using speech therapy with hijaiyyah letters, with the result of statistic exam there is mark $p ; 0,000$ (with $\alpha ; 0,05$ ). Suggest it is important to increase the treatment for stroke patients through giving complete information commit therapyst.
\end{abstract}

Keywords-Speech Therapy, Hijaiyyah, Verbal Communication

\section{INTRODUCTION}

Stroke is a major cerebrovascular disorder in the United States and various countries in the world. Data on causes of death from the 1990s have shown that cerebrovascular diseases remain a leading cause of death. In 2001 it was estimated that cerebrovascular diseases (stroke) accounted for 5.5 million deaths world wide, equivalent to $9.6 \%$ of all deaths[1]. Stroke is ranked as the second leading cause of death worldwide with an annual mortality rate of about 5.5 million. Not only does the burden of stroke lie in the high mortality but the high morbidity also results in up to $50 \%$ of survivors being chronically disabled.[2]

Stroke is a major cerebrovascular disorder in the United States and various countries in the world. Data on causes of death from the 1990s have shown that cerebrovascular diseases remain a leading cause of death. In 2001 it was estimated that cerebrovascular diseases (stroke) accounted for 5.5 million deaths world wide, equivalent to $9.6 \%$ of all deaths[1]. Stroke is ranked as the second leading cause of death worldwide with an annual mortality rate of about 5.5 million. Not only does the burden of stroke lie in the high mortality but the high morbidity also results in up to $50 \%$ of survivors being chronically disabled.[2]

Data from Loekmono Hadi Kudus General Hospital there is an average of 36 stroke patients each month who are hospitalized. Of the average $60 \%$ of patients who experience aphasia with complaints of difficulty speaking, the tongue feels stiff and difficult to move (Medical Notes Kudus General Hospital).

Handling of aphasia in stroke patients depends on the severity of aphasia and accompanying stroke symptoms. Aphasia accompanied by paralysis in other parts of the body needs special therapy, including physiotherapy, occupational therapy, and speech therapy[4].Speech therapy is believed to increase $85 \%$ of language skills significantly, there are ongoing improvements also occur in these patients for 6 months. Research results from speech therapy, the researchers also found that an increase can occur regardless of the age of stroke patients or the severity of language disorders[5].

Based on the observations of researchers hijaiyyah letters are the letters often spoken by the majority of people in Kudus with the habit of pronouncing Arabic letters during prayer or reading the Qur'an. Hijaiyyah letters are more familiar in Kudus society so that they are easier said and taught. Hijaiyyah letters also involve more muscle movements rather than Latin letters. Preliminary survey of researchers in August 2019 at the Loekmono Hadi Kudus Hospital on 5 stroke patients who had aphasia when asked to pronounce hijaiyyah letters they felt easier and helped in restoring speech.

\section{RESEARCH METHOD}

This study uses an experimental research method with one-group pre-test-post-test design (Sugiono, 2010). The design of this study was to measure the ability of speech before speech therapy was carried out using hijaiyyah letters and the measurement of speech ability again using the Tadir Test afterwards. Speech therapy using hijaiyyah is done for 10 times therapy for 5 consecutive days.

The population in this study were stroke patients at the Loekmono Hadi Kudus General Hospital with an average of 36 patients a month. The sample of this study uses 
accidental sampling with the main criteria for stroke patients who experience aphasia with good awareness as many as 20 patients.

The data in this study were analyzed using a computer program. Presentation of data is in the form of categorical data while the influence test uses Wilcoxon test.

\section{RESEARCH RESULTS}

\section{A. Univariate Analysis}

The results showed that the average age of respondents was 56 years with the lowest age of 43 years and the highest 78 years. Respondents with male gender are 8 people (40\%) and women are 12 people (60\%). Most respondents work as farmers as 12 people $(60 \%)$, traders 6 people $(30 \%)$ and civil servants as many as 2 people $(10 \%)$. The education level of elementary school respondents are 24 people $(70 \%)$, junior high school 3 people $(15 \%)$, senior high school 2 people $(10 \%)$ and 1 person college $(5 \%)$.

1. The level of speech ability before treatment

TABLE I. FREQUENCY DISTRIBUTION BASED ON THE ABILITY TO SPEAK BEFORE THE SPEECH THERAPY EXERCISE HIJAIYYAH LETTERS OF STROKE PATIENTS AT LOEKMONOHADI HOSPITAL KUDUS

\begin{tabular}{|c|c|c|}
\hline Speech Disorders & & yah Exercise \\
\hline \multicolumn{2}{|c|}{ Frequency } & Percent \\
\hline Severe speech disorder & 2 & 10 \\
\hline Moderate speech disorder & 12 & 60 \\
\hline Mild speech disorders & 6 & 30 \\
\hline Does not experience speech disorders & 0 & 0 \\
\hline Total & 20 & 100.0 \\
\hline
\end{tabular}

Based on table I above shows that the level of speech ability before speech therapy letters hijaiyyah the majority of medium speech disorders as many as 12 respondents
$(60 \%)$, a minimum of severe speech disorder 2 people $(10 \%)$.

2. Speech level after treatment

TABLE II. FREQUENCY DISTRIBUTION BASED ON SPEECH ABILITY AFTER HIJAIYYAH SPEECH THERAPY EXERCISE FOR STROKE PATIENTS AT DR. DR. LOEKMONOHADI KUDUS

\begin{tabular}{|c|c|c|}
\hline \multicolumn{1}{|c|}{ Speech Disorders } & \multicolumn{2}{c|}{ Speech Therapy Hijaiyyah Exercise } \\
\hline \multicolumn{1}{|c|}{ Frequency } & & Percent \\
\hline Severe speech disorder & 0 & 0 \\
\hline Moderate speech disorder & 5 & 25 \\
\hline Mild speech disorders & 15 & 75 \\
\hline Does not experience speech disorders & 0 & 0 \\
\hline Total & 20 & 100.0 \\
\hline
\end{tabular}

Based on table II above shows that the level of ability to speak after speech therapy letters hijaiyyah the majority of mild speech disorders as many as 15 respondents $(75 \%)$, a minimum of moderate speech disorders 5 people $(25 \%)$.

B. Bivariate Analysis

TABLE III. DISTRIBUTION OF THE FREQUENCY OF SPEECH DIFFERENCE BEFORE AND AFTER THE SPEECH THERAPY HIJAIYYAH EXERCISE FOR STROKE PATIENTS AT DR. DR. LOEKMONOHADI KUDUS

\begin{tabular}{|c|c|c|c|}
\hline SPEECH DISORDERS & \multicolumn{2}{|c|}{$\begin{array}{l}\text { SPEECH THERAPY HIJAIYYAH } \\
\text { EXERCISE }\end{array}$} & $\begin{array}{c}\mathrm{P} \\
\text { VALUE }\end{array}$ \\
\hline 1. & BEFORE & AFTER & \\
\hline SEVERE SPEECH DISORDER & 2 & 0 & 0,000 \\
\hline MODERATE SPEECH DISORDER & 12 & & 5 \\
\hline MILD SPEECH DISORDERS & 6 & & 15 \\
\hline DOES NOT EXPERIENCE SPEECH DISORDERS & 0 & & 0 \\
\hline TOTAL & 20 & & 20 \\
\hline
\end{tabular}

From table III above regarding the results of paired tests on the ability to speak respondents before and after the speech there is a significant difference between the average ability of the respondents to speak before and after speech therapy hijaiyyah. The difference seen in the respondent's approval before hijaiyyah speech therapy is a speech disorder that is happening when talking about 
speech difficulties with the Wilcoxon statistical test results getting a real value $(\mathrm{p} ; 0,000 \alpha ; 0.05)$.

\section{DISCUSSION}

Based on the results of research conducted a significant difference between the ability to speak before and after speech therapy done letters hijaiyyah in stroke patients Dr. Loekmono Hadi General Hospital. This relates to the improvement in the ability to speak of patients who have difficulty speaking as many as 15 respondents $(75 \%)$, the results of statistical tests obtained from the added value ( $\mathrm{p}$; $0,000 \alpha ; 0.05)$.

The results of talking therapy using hijaiyyah after being treated are treated for 5 consecutive days with a frequency of $2 \mathrm{x}$ a day. In this study it was seen that respondents who participated in the Islamic religion were very familiar with the pronunciation of the letters hijaiyyah because in their health these letters were often pronounced especially in prayer. Researcher's observations also prove that there is a difference in the tongue during the exercise 5 days ago - this is evidenced by the existence of a tongue that has undergone improvement. Speech therapy is an action given to individuals who experience communication disorders, speech disorders, recovery disorders. This speech therapy supports patients with neurological problems, approved by stroke patients. Hijaiyyah therapy is a fonomotor therapy in which the patient determines hijaiyyah fenom which is mostly done by the people of Indonesia. This therapy is one that replaces the ability to speak with motor aphasia[6][7]

Research conducted by Ghoffar Dwi Agus Haryanto, Dody Setyawan, Muslim Argo Bayu Kusuma entitled the effect of AIUEO therapy on speech ability in stroke patients who experience motor aphasia at the Tugurejo District Hospital Semarang in 2014, states that based on the results of research on 21 subjects treated AIUEO therapy can be concluded that the ability to speak begins to increase on day 3 after being given AIUEO therapy, while the effect of aiueo therapy becomes significant in improving speech ( $p$ value $<0.05$ ) starting from day 5 to day7 . The study consisted in hopital of 33 patients being hospitalized for stroke rehabilitation in our hospital with first stroke but without previous history of speech and language therapy. Sixteen sessions of impairment-based speech and language therapy were applied to the patients, 30-60 minutes per day, 2 days a week, for 8 successive weeks. Aphasia assessment in stroke patients was performed with Gülhane Aphasia Test-2 before and after treatment. Compared with before treatment, fluency of speech, listening comprehension, reading comprehension, oral motor evaluation, automatic speech, repetition and naming were improved after treatment. This suggests that 16 seesions of speech and language therapy, 30-60 minutes per day, 2 days a week, for 8 successive weeks, are effective in the treatment of aphasic patients with subacute stroke[8].[9][10]

\section{CONCLUSION}

- The ability of respondents to speak before being given speech therapy letters hijaiyyah the majority of medium disorders by 12 respondents $(60 \%)$

- The ability of respondents to speak after being given speech therapy letters hijaiyyah the majority of mild disturbances by 15 respondents $(75 \%)$

- There is a significant difference between the conditions of the respondents before being given speech therapy and those who have been given speech therapy. Judging from the Wilcoxon test with a $p$ value of $0.00<\alpha 0.05$; so it can be concluded that there is an effect of speech therapy on verbal communication skills in stroke patients.

\section{RECOMMENDATIONS}

\section{A. Nursing Research}

Researchers recommend that further research can be provide longer treatment for aphasia patients, so that patients will be receive more frequency of action so that changes in aphasia patients' development will be more visible.

\section{B. Nursing Services}

It is better to conduct speech therapy training for nurses on duty at the hospital so that it is expected to play an active role with their knowledge to socialize to family and environment, so that independent family health care can be created.

\section{REFERENCES}

[1] T. Truelsen, S. Begg, and C. Mathers, "The global burden of cerebrovascular disease," Glob. Burd. Dis., pp. 1-67, 2000.

[2] E. S. Donkor, "Stroke in the 21st Century: A Snapshot of the Burden, Epidemiology, and Quality of Life," Stroke Res. Treat., vol. 2018, 2018, doi: 10.1155/2018/3238165.

[3] J. Misbach and W. Ali, "Stroke in Indonesia: a first large prospective hospital-based study of acute stroke in 28 hospitals in Indonesia.," J. Clin. Neurosci., vol. 8, no. 3, pp. 245-9, May 2001, doi: 10.1054/jocn.1999.0667.

[4] A. M. Al Khathaami et al., "Characteristics and Outcomes of Younger Adults with Embolic Stroke of Undetermined Source (ESUS): A Retrospective Study," Stroke Res. Treat., vol. 2019, 2019, doi: 10.1155/2019/4360787.

[5] N. Kato, V. Prinz, J. Dengler, and P. Vajkoczy, "Blood Flow Assessment of Arteriovenous Malformations Using Intraoperative Indocyanine Green Videoangiography," Stroke Res. Treat., vol. 2019, 2019, doi: 10.1155/2019/7292304.

[6] J. A. Legh-Smith, R. Denis, P. M. Enderby, D. T. Wade, and R. Langton-Hewer, "Selection of aphasic stroke patients for intensive speech therapy," J. Neurol. Neurosurg. Psychiatry, vol. 50, no. 11, pp. 1488-1492, 1987, doi: 10.1136/jnnp.50.11.1488.

[7] I. Sofiatun, S. P. Kristiyawati, and E. C. Purnomo, "Efektifitas Terapi AIUEO dan Terapi The Token Test terhadap Kemampuan Berbicara Pasien Stroke yang Mengalami Afasia Motorik Di Rs Mardi Rahayu Kudus.," Poltekkes Kemenkes Semarang, vol. 3, no. 2, pp. 230-238, 2015.

[8] E. A. Gebreyohannes, A. S. Bhagavathula, T. B. Abebe, M. A. Seid, and K. T. Haile, "In-Hospital Mortality among Ischemic Stroke Patients in Gondar University Hospital: A Retrospective Cohort Study," Stroke Res. Treat., vol. 2019, 2019, doi: $10.1155 / 2019 / 7275063$.

[9] I. Setyopranoto et al., "Prevalence of stroke and associated risk factors in sleman district of Yogyakarta Special Region, Indonesia," Stroke Res. Treat., vol. 2019, 2019, doi: $10.1155 / 2019 / 2642458$.

[10] “Jurnal Ners LENTERA, Vol. 6, No. 1, Maret 2018 Pengaruh Pendidikan Kesehatan Media,” vol. 6, no. 1, pp. 78-88, 2018. 